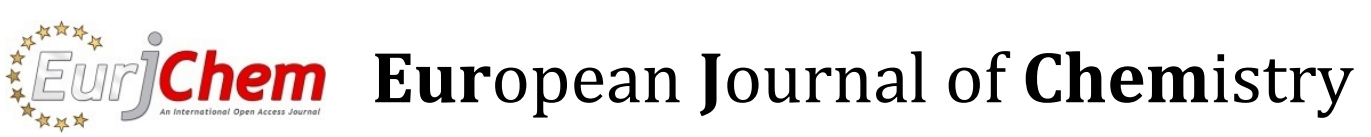

Check for updates

\section{Complexation equilibria of ambroxol hydrochloride in solution by potentiometric and conductometric methods}

\author{
Ahmed Hosny Naggar (D) 1,*, Hammed Mohammed Al-Saidi (D) 2, Othman Abd El-Moaty Farghaly (D) 1, \\ Taher Mohammed Hassan (D) 3 and Salma Zaidan Mohamed Bortata (DD 3
}

${ }^{1}$ Chemistry Department, Faculty of Science, Al-Azhar University, Assiut Branch, 71524, Assiut, Egypt

ahnayoub@azhar.edu.eg (A.H.N.),othman15@yahoo.com (O.A.E.F.)

2 Department of Chemistry, University College in Al-Jamoum, Umm Al-Qura University, 21955, Makkah, Kingdom of Saudi Arabia hmsaidi@uqu.edu.sa (H.M.A.)

${ }^{3}$ Chemistry Department, Faculty of Science, Sebha University, Sebha, Libya

tahermhassan2018@gmail.com (T.M.H.), salmazmbortata2018@gmail.com (S.Z.M.B.)

* Corresponding author at: Chemistry Department, Faculty of Science, Al-Azhar University, Assiut Branch, 71524, Assiut, Egypt. Tel: +2.088.2148095 Fax: +2.088.2148093 e-mail: ahnayoub@azhar.edu.eg (A.H. Naggar).

\section{RESEARCH ARTICLE}

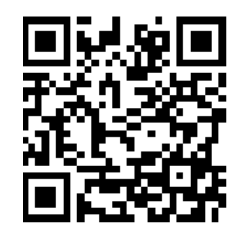

10.5155/eurjchem.9.1.49-56.1682

Received: 04 January 2018

Received in revised form: 06 March 2018 Accepted: 06 March 2018

Published online: 31 March 2018

Printed: 31 March 2018

\section{KEYWORDS}

Potentiometry

Conductometry

Metal complexes

Stability constants

Ambroxol hydrochloride

Species distribution diagrams

\section{Introduction}

Ambroxol hydrochloride $\left(\mathrm{C}_{13} \mathrm{H}_{19} \mathrm{Br}_{2} \mathrm{~N}_{2} \mathrm{OCl}\right)$, is chemically known as trans-4-(2-amino-3,5-dibromobenzyl-amino)cyclohexanol hydrochloride, and its chemical structure is shown in Figure 1. AMB is a pharmacologically active metabolite of bromhexine and it is potent mycolytic activity. AMB is used in the treatment of bronchial asthma and chronic bronchitis. It is used as expectorant since it acts as an antiglue factor by reducing the adhesion of mucus to the bronchial wall, in improving its transport and in providing protection against infection and irritating agents. AMB is often used in adjuvant therapy of chronic obstructive pulmonary disease and other chronic respiratory disorders [1-3]. It increases the production of surfactant by type II pneumocytes [4], accelerates the maturation of fetal lung [5], and therefore has also been used in the treatment of infant respiratory distress syndrome [6]. It is officially reported in British Pharmacopeia [7] and Indian Pharmacopeia [8].
The formation constants of $\mathrm{Li}(\mathrm{I}), \mathrm{Mg}(\mathrm{II}), \mathrm{Sr}(\mathrm{II}), \mathrm{Ca}(\mathrm{II}), \mathrm{Mn}(\mathrm{II}), \mathrm{Co}(\mathrm{II}), \mathrm{Ni}(\mathrm{II}), \mathrm{Cu}(\mathrm{II}), \mathrm{Zn}(\mathrm{II})$, (AMB) were calculated using the half- $\bar{n}$ value. In presence of $0.1 \mathrm{M} \mathrm{NaNO}_{3}$, metal ions such as $\mathrm{Zn}(\mathrm{II}), \mathrm{Cd}(\mathrm{II}), \mathrm{Ni}(\mathrm{II}), \mathrm{Cr}(\mathrm{III}), \mathrm{Li}(\mathrm{I}), \mathrm{Mg}(\mathrm{II})$ and $\mathrm{Al}(\mathrm{III})$ forms three types of metal-ligand complexes 1:1 and 1:2 (M:L). For ligand protonation constants, two logarithmic association constant values were calculated by the half- $\bar{n}$ method and are 10.7 and 7.6, respectively. The effect of ionic strength on stability constant of AMP, with different metal ions viz. Fe(III), $\mathrm{Th}(\mathrm{IV}), \mathrm{Al}(\mathrm{III}), \mathrm{Cr}(\mathrm{III})$ and $\mathrm{Cu}(\mathrm{II})$ was studied. Based on relationship between the ionic stability constants of the formed metal-ligand complex (1:1) were decreased as the ionic by conductometric method and it is found to be of 1:1, 1:2 and/or 1:3 (M:L) complex species

Cite this: Eur. J. Chem. 2018, 9(1), 49-56 Journal website: $\underline{w w w . e u r j c h e m . c o m}$<smiles>Nc1c(Br)cc(Br)cc1CNC1CCC(O)CC1</smiles>

Figure 1. Structure for AMB.

The realization of the interaction between biologically active molecules and metals is extremely important. Such interactions occupy prominence in the field of medicinal inorganic chemistry where it is offer great possibilities in biomaterials preparation process, considering certain aspects of biocompatibility or even in design of therapeutic agents, which are not readily available to organic compounds [9-11]. Actually, therapeutic value of the metal-drug complexes has encouraged the researcher to improve on new alternative drugs $[12,13]$. 
As an electrochemical method, the potentiometric method is considered as most applicable technique in many branches of solution chemistry since it is most simple, accurate and widely applicable technique in studies required accomplishing the required studies related to ionic equilibria of different complexes [14]. A wide application of potentiometric methods in study of binary and ternary complexes formed between molecules of biological and pharmaceutical interest (as ligand) and transition metals [15-28]. Potentiometric study of such complexes formed between drugs and metal ions supplies us how drug-metal interactions may affect drug delivery to target cell [29-31].

From our literature survey, we can conclude that little information about the determination of stability constants of formed complexes between AMB and several metal ions under investigation using potentiometric and conductometric methods were available. Mixed dissociation constants of five drug acids: AMB, antazoline, naphazoline, oxymetazoline and ranitidine, at various ionic strengths (I) of range 0.01 and 1.00 and at temperatures of 25 and $37^{\circ} \mathrm{C}$ were determined using SQUAD regression analysis of the $\mathrm{pH}$-spectrophotometric titration data [32].

Herein, to the best of our knowledge, no attentions had been made to investigate the potentiometric and conductometric behavior of $\mathrm{AMB}$ with studied metal ions viz; $\mathrm{Li}(\mathrm{I})$, $\mathrm{Mg}(\mathrm{II}), \mathrm{Sr}(\mathrm{II}), \mathrm{Ca}(\mathrm{II}), \mathrm{Mn}(\mathrm{II}), \mathrm{Co}(\mathrm{II}), \mathrm{Ni}(\mathrm{II}), \mathrm{Cu}(\mathrm{II}), \mathrm{Zn}(\mathrm{II}), \mathrm{Cd}(\mathrm{II})$, $\mathrm{Ba}(\mathrm{II}), \mathrm{Pb}(\mathrm{II}), \mathrm{Al}(\mathrm{III}), \mathrm{Cr}(\mathrm{III}), \mathrm{Fe}(\mathrm{III})$ and $\mathrm{Th}(\mathrm{IV})$. Complexation equilibria in solution were studied by potentiometric and conductometric methods. Experimental data were treated by both graphical and numerical calculation methods, which enabled the establishment of the species in solution and calculation of the respective stability constants. The study involves also, the effect of ionic strength on stability constants.

\section{Experimental}

\subsection{Instrumentation}

All $\mathrm{pH}$ measurements were carried out on Jenway $\mathrm{pH}$ meter, using combined glass electrode (accurate total $0.01 \mathrm{pH}$ units). Conductometric titration measurements were carried out using Jenway 4320 model conductivity meter, using an immersion cell. The electrode system was calibrated in terms of hydrogen ion concentrations instead of activities; thus, all constants determined in this work are concentration constants. The stoichiometry and stability constants were calculated using numerical and computerized programs (MS Excel) [33].

\subsection{Chemicals and materials}

Ambroxol hydrochloride (AMB) (Al-Maya Pharmaceutical Factory, Tripoli, Libya) was purchased from Merck as biochemical grade reagents. All studied metal ions; (Li(I), $\mathrm{Mg}(\mathrm{II}), \mathrm{Sr}(\mathrm{II}), \mathrm{Ca}(\mathrm{II}), \mathrm{Mn}(\mathrm{II}), \mathrm{Co}(\mathrm{II}), \mathrm{Ni}(\mathrm{II}), \mathrm{Cu}(\mathrm{II}), \mathrm{Zn}(\mathrm{II}), \mathrm{Cd}(\mathrm{II})$, $\mathrm{Ba}(\mathrm{II}), \mathrm{Pb}(\mathrm{II}), \mathrm{Al}(\mathrm{III}), \mathrm{Cr}(\mathrm{III}), \mathrm{Fe}(\mathrm{III})$ and $\mathrm{Th}(\mathrm{IV})$ ions) were purchased as nitrates (BDH, UK, GENEVA or INDIA). Sodium hydroxide, sodium nitrates and nitric acid were analytical grades and were purchased from BDH and Carlo Erba. All solutions used in current article were prepared by using double-distilled $\mathrm{CO}_{2}$-free water and stored in the refrigerator.

\subsection{Procedures}

\subsubsection{Potentiometric titrations}

The proposed method in current work consisted of making potentiometric measurments of hydrogen ion concentration solution of AMB in the presence and absence of the studied metal ions [30]. The titration was performed in the presence of
$0.1 \mathrm{M}$ sodium nitrate. Generally, three sets of solutions; (a) $0.01 \mathrm{M} \mathrm{HNO}_{3}+0.09 \mathrm{M} \mathrm{NaNO}_{3}$, (b) Solution (a) + 0.001 M AMB (c) Solution (b) $+0.001 \mathrm{M}$ metal ion, were prepared and titrated against standared $\mathrm{CO}_{2}$-free $\mathrm{NaOH}$ solution at room temperature. In all titrations, the total volume was maintained constant at $50 \mathrm{~mL}$ and ionic strength $0.1 \mathrm{M} \mathrm{NaNO}_{3}$ and $25 \pm 0.1$ ${ }^{\circ} \mathrm{C}$. Multiple titrations were carried out for each system. The $\mathrm{pH}$-meter was calibrated before and after each titration using three standard buffer solutions at $\mathrm{pH}=4.01,7.00$ and 10.00 .

\subsubsection{Conductometric titrations}

Conductometric titrations were carried out at room temperature $\left(25 \pm 0.1^{\circ} \mathrm{C}\right)$ by titrating $25.0 \mathrm{~mL}$ of $1 \times 10^{-3} \mathrm{M}$ of each metal ion solution with $1 \times 10^{-2} \mathrm{M}$ of AMB solution in 0.5 $\mathrm{mL}$ increments. Correction for the dilution effect is performed by multiplying the values of specific conductance by factor; $\underline{25+V}$, where $V$ is volume of titrant added.

$$
25
$$

\section{Results and discussion}

\subsection{Potentiometric studies of AMB with some metal ions}

\subsubsection{Determination of the proton-ligand stability constants of $A M B$}

Potentiometric titration of AMB in the presence of $0.01 \mathrm{M}$ $\mathrm{HNO}_{3}$ was carried out. The protonation constant of AMB and stability constants of the formed complexes between AMB and studied metal ions have been calculated and tabulated at different ionic strengths; $\mathrm{I}=0.1,0.2$ and $0.3 \mathrm{M} \mathrm{NaNO}_{3}$ aqueous solution which adjusted by addition of $\mathrm{NaNO}_{3}$ at $25 \pm 0.1{ }^{\circ} \mathrm{C}$ and using $\mathrm{CO}_{2}$-free $\mathrm{NaOH}$ solution as a titrant. The titration curves are shown in Figure 2a-d.

According to Irving and Rossotti [34], calculations of proton-ligand formation constants was carried out by plotting $\bar{n} A$ against $\mathrm{pH}$ (plotted curves based on titration of solutions $a$ and $b$ ). The average number of proton attached per ligand, $\bar{n} A$ was calculated at different $\mathrm{pH}$ values using Irving and Rossotti equations [34]

$$
\bar{n} A=Y+\frac{\left(V_{1}-V_{2}\right)\left(N^{o}+E^{o}\right)}{\left(V_{o}+V_{1}\right) T_{c} L^{o}}
$$

where $Y=2$ (number of dissociable protons in the AMB), $V_{\mathrm{o}}$ is the initial volume, $V_{1}$ and $V_{2}$ are the volume of alkali required to reach the same $\mathrm{pH}$ in $\left(\mathrm{HNO}_{3}\right)$ and $\left(\mathrm{HNO}_{3}+\mathrm{AMB}\right)$ solutions, respectively. $T_{C} L^{\circ}$ is the total AMB concentration, $N^{\circ}$ is the normality of the alkali and $E^{\mathrm{o}}$ is the initial concentration of free acid. Calculation of proton ligand dissociation constants were carried out by plotting $\bar{n} A$ against $\mathrm{pH}$ at $0.1 \mathrm{M} \mathrm{NaNO}_{3}$ ionic strength as shown in Figure 3. The reaction mechanism is shown in Scheme 1.

The values of $\log K_{1}^{H}$ and $\log K_{2}^{H}$ (the first and second proton dissociation constants of the AMB) are the $\mathrm{pH}$ values corresponding to $\bar{n} A=0.5$ and 1.5 , respectively. It is worth mentioning that the ligand do not hydrolyses under the experimental conditions. This is indicated by the rapid attainment of equilibrium during titration time.

\subsubsection{Determination of formation constants of metal-AMB complexes}

The $\mathrm{pH}$-metric titration of sixteen metal salts viz; $\mathrm{Li}(\mathrm{I}), \mathrm{Mg}$ (II), $\mathrm{Sr}(\mathrm{II}), \mathrm{Ca}(\mathrm{II}), \mathrm{Mn}(\mathrm{II}), \mathrm{Co}(\mathrm{II}), \mathrm{Ni}(\mathrm{II}), \mathrm{Cu}(\mathrm{II}), \mathrm{Zn}(\mathrm{II}), \mathrm{Cd}(\mathrm{II})$, $\mathrm{Ba}(\mathrm{II}), \mathrm{Pb}(\mathrm{II}), \mathrm{Al}(\mathrm{III}), \mathrm{Cr}(\mathrm{III}), \mathrm{Fe}(\mathrm{III})$ and $\mathrm{Th}(\mathrm{IV})$ were selected to elucidate their interaction with AMB using potentiometric method. 

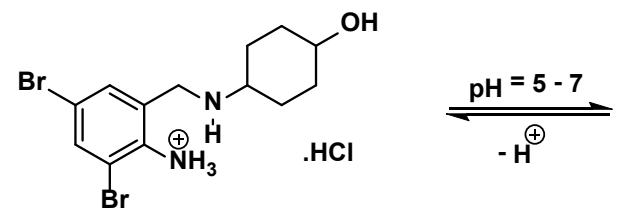<smiles>Nc1c(Br)cc(Br)cc1CNC1CCC(O)CC1</smiles><smiles>Nc1c(Br)cc(Br)cc1CNC1CCC(O)CC1</smiles>

Scheme 1. The reaction mechanism of AMB
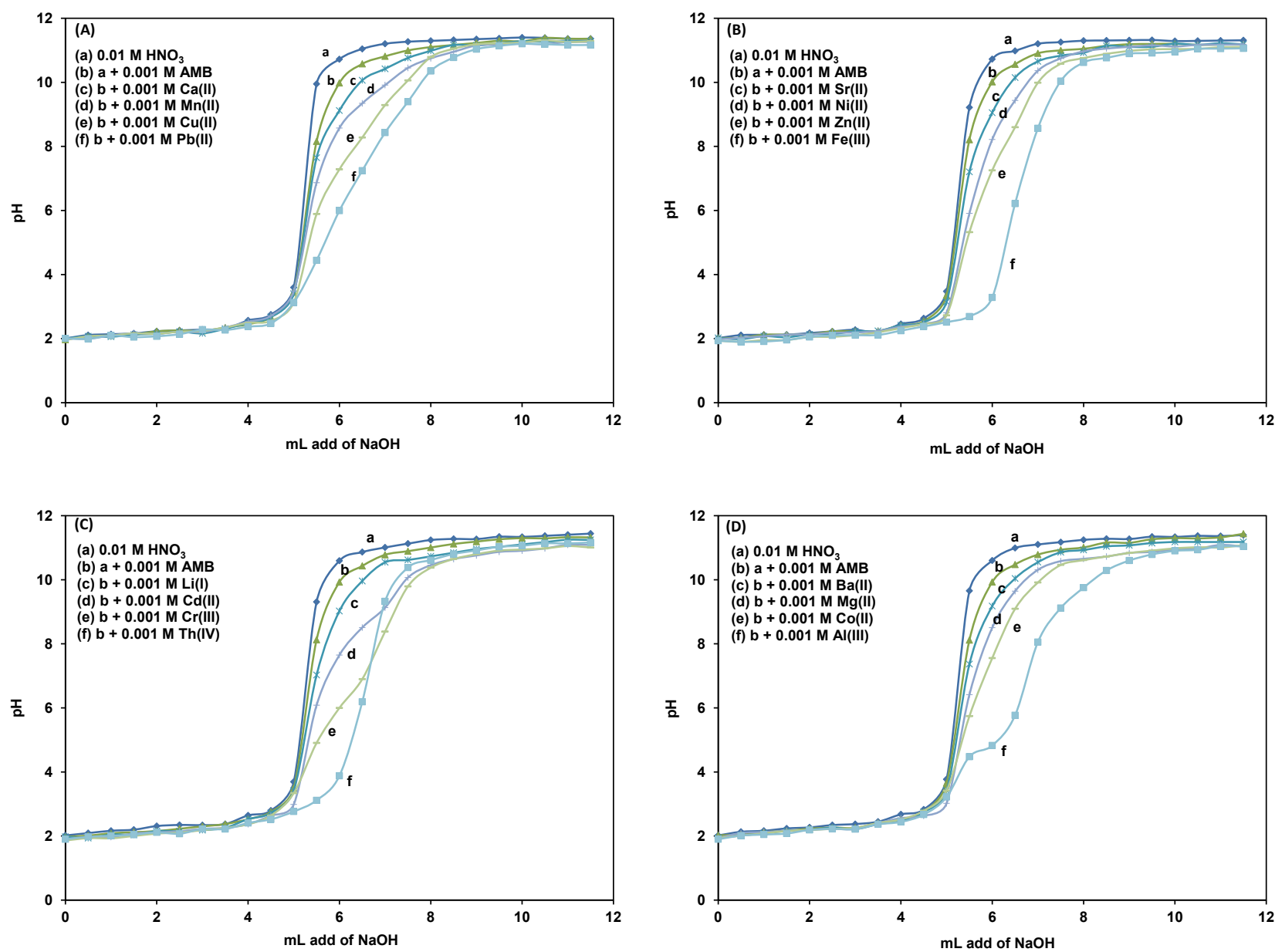

Figure 2. Potentiometric titration curves of $\mathrm{AMB}$, at $0.1 \mathrm{M} \mathrm{NaNO}_{3}$ and $25 \pm 0.1{ }^{\circ} \mathrm{C}$ in presence of $1 \times 10^{-3} \mathrm{M}$ of studied metal ions.

The protonation constant of the compound and stability constants of complexes formed were calculated using ionic strength, $\mathrm{I}=0.1 \mathrm{M} \mathrm{NaNO}_{3}$ in aqueous solutions at $25 \pm 0.1{ }^{\circ} \mathrm{C}$ and using $\mathrm{CO}_{2}$-free $\mathrm{NaOH}$ solution as a titrant.

In Figure 2a-d, it can be seen that the titration curves of the metal ion-AMB solutions (c) are well separated from that curves of free AMB solution (b). Thus, replacement of $\mathrm{H}^{+}$ion is due to complexation. From these titration curves, $\bar{n}$ (average number of AMB molecules attached per metal ion) and $p L$ (free ligand exponent) values were calculated using Irving and Rossotti equations [34].

$\bar{n}=\frac{\left(V_{3}-V_{2}\right)\left(N^{o}+E^{o}\right)}{\left(V_{o}+V_{2}\right) \bar{n} H T_{c} M^{o}}$

$p L=\log \left[\frac{1+\beta_{1}\left[H^{+}\right]+\beta_{2}\left[H^{+}\right]^{2}}{\left(T_{c} l^{o}-\bar{n} T_{c} M^{o}\right)} \times \frac{V_{o}+V_{3}}{V_{o}}\right]$ where $V_{1}, V_{2}, V_{3}$ are the amounts of alkali to reach the same $\mathrm{pH}$ in: free acid (curve $a$ ), free acid + AMB (curve $b$ ) and free acid $+\mathrm{AMB}+$ metal ion (curves $c-f$ ), respectively. $V_{\mathrm{o}}$ is the original volume $(50 \mathrm{~mL})$ of the mixtures, $T_{c} M^{\circ}$ denotes the total concentration of metal present in the solution. The $\bar{n}$ values were plotted against the corresponding $p L$ values to get the formation curves of the metal complexation equilibria. The formation curves are shown in Figure 4a-d. From these formation curves, the values of stability constants at $0.1 \mathrm{M}$ $\mathrm{NaNO}_{3}$ ionic strength listed in Table 1 were determined using the half-integral method [34].

Looking at the Table 1, we can conclude that the formed complexes between $\mathrm{AMB}$ and some metal ions viz; $\mathrm{Ca}(\mathrm{II})$, $\mathrm{Mn}(\mathrm{II}), \mathrm{Cu}(\mathrm{II}), \mathrm{Ba}(\mathrm{II}), \mathrm{Pb}(\mathrm{II}), \mathrm{Fe}(\mathrm{III})$ and $\mathrm{Th}(\mathrm{IV})$, the formation constants of the first complex was only obtained in $\mathrm{pH}$ range up to 12 , since the formation of the second one is disturbed by hydrolyses and precipitation of the metal ion. Therefore, the experimental data in this $\mathrm{pH}$ range would not be useful in the numerical calculations. 


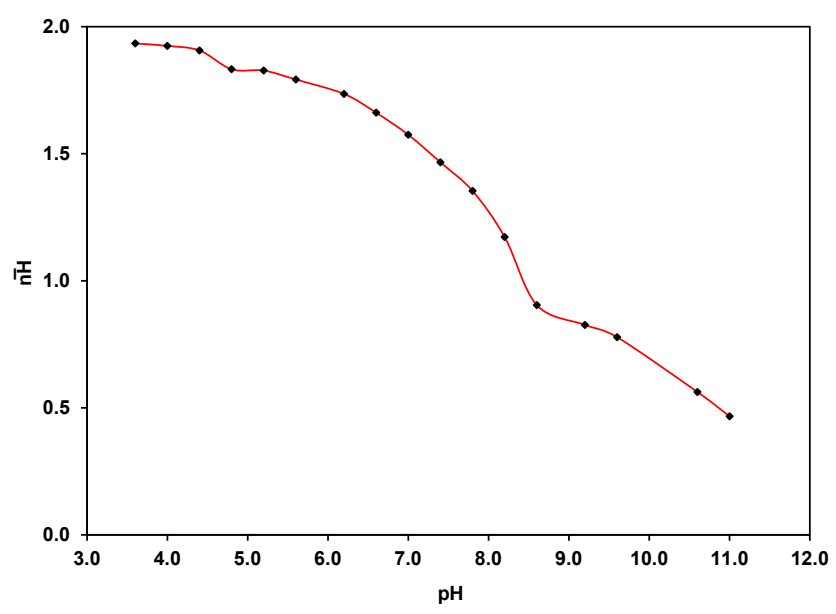

Figure 3. Protonation constant curve of $\mathrm{AMB}$ at $0.1 \mathrm{M} \mathrm{NaNO}_{3}$ and $25 \pm 0.1^{\circ} \mathrm{C}$.
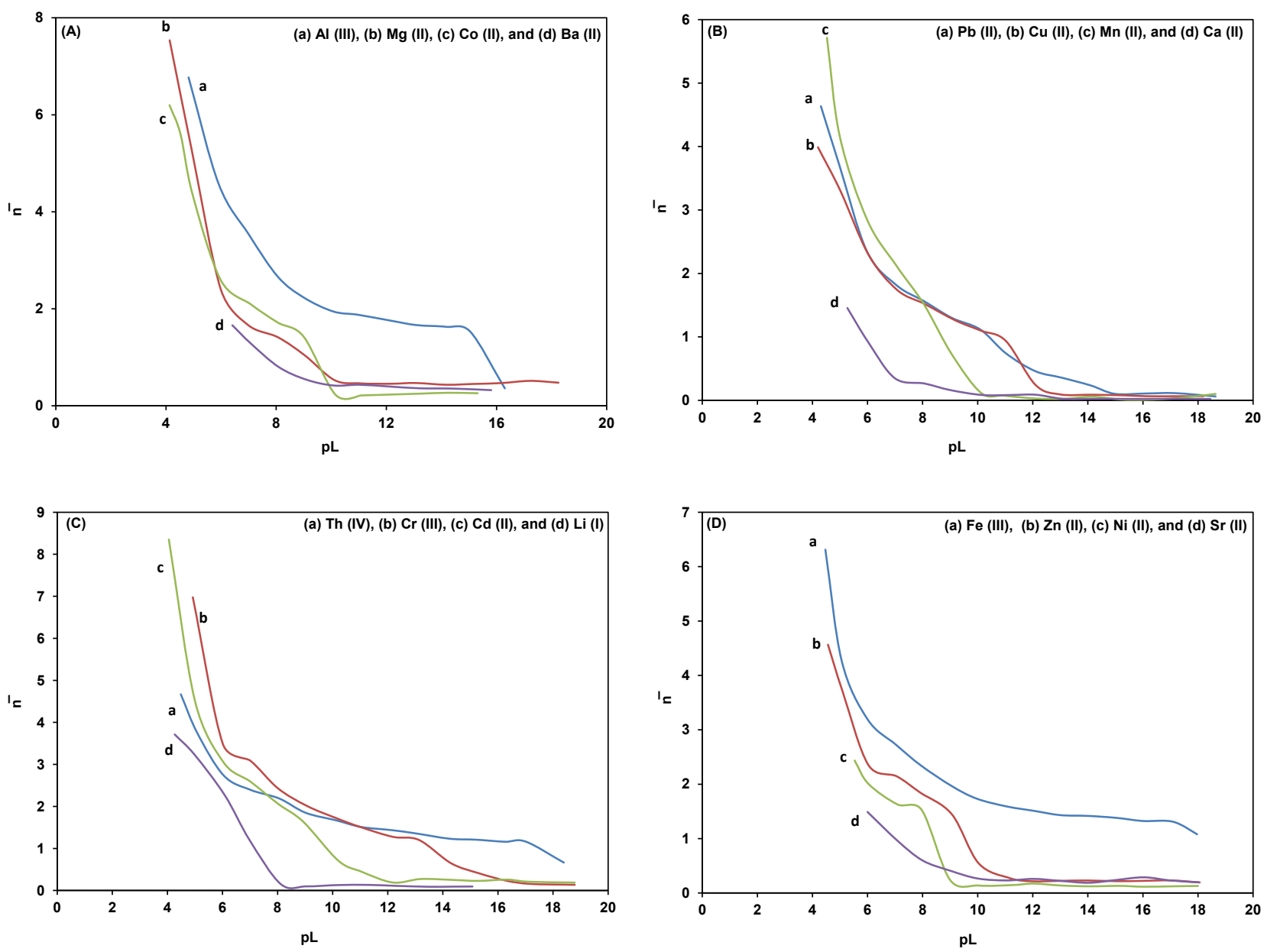

Figure 4. Formation curves of binary complexes formed between $\mathrm{AMB}$ at $0.1 \mathrm{M} \mathrm{NaNO}_{3}$ and $25 \pm 0.1{ }^{\circ} \mathrm{C}$ in presence of $1 \times 10^{-3} \mathrm{M}$ of studied metal ions.

Moreover, these data cannot be considered to be at equilibrium, since the $\mathrm{pH}$ readings at this stage showed unsteady drift.

Furthermore, some metal ions such as $\mathrm{Zn}(\mathrm{II}), \mathrm{Cd}(\mathrm{II}), \mathrm{Ni}(\mathrm{II})$, $\mathrm{Cr}(\mathrm{III}), \mathrm{Li}(\mathrm{I}), \mathrm{Mg}(\mathrm{II})$ and $\mathrm{Al}(\mathrm{III})$ have ability to form three types of metal-AMB complexes; 1:1, 1:2 and 1:3, at the ionic strength under investigation, but the other metal ions ( $\mathrm{Sr}$ (II), and Co (II)) tend to form only two types of metal-AMB complexes; $1: 1$ and 1:2 (M:L). This may be due to the concentration of AMB, ionic strength and the nature of metal ion.

AMB has two sites, the first site is the deprotonation of protonated amino group $\left(\mathrm{NH}_{3}\right)$ and the other site is the dissociation of proton in the imino group $\left(\mathrm{NH}_{3}\right)^{+}$. These sites are shown as follow where (M:L) ratio is (1:1) (Figure 5). 
Table 1. Protonation constants of $\mathrm{AMB}$ and stability constants of metal ion complexes using potentiometric and conductometric methods at $0.1 \mathrm{M} \mathrm{NaNO}_{3}$ and $25 \pm 1^{\circ} \mathrm{C}$.

\begin{tabular}{|c|c|c|c|}
\hline Metal ion & $\log K_{1}(\mathrm{M}: \mathrm{L})^{*}$ & $\log K_{2}(\mathrm{M}: \mathrm{L}){ }^{*}$ & $\log K_{3}(\mathrm{M}: \mathrm{L}) *$ \\
\hline $\mathrm{H}^{+}$ & 10.70 & 7.60 & - \\
\hline Al(III) & $15.70(1: 1)$ & $12.93(1: 2)$ & $8.15(1: 3)$ \\
\hline $\mathrm{Mn}(\mathrm{II})$ & $9.32(1: 1)$ & - & - \\
\hline $\mathrm{Pb}(\mathrm{II})$ & $12.62(1: 1)$ & - & - \\
\hline $\mathrm{Ba}(\mathrm{II})$ & $8.45(1: 1)$ & - & - \\
\hline $\mathrm{Ca}(\mathrm{II})$ & $6.82(1: 1)$ & - & - \\
\hline $\mathrm{Cd}(\mathrm{II})$ & $10.40(1: 1)$ & $8.98(1: 2)$ & $7.25(1: 3)$ \\
\hline $\mathrm{Co}(\mathrm{II})$ & $9.12(1: 1)$ & $8.48(1: 2)$ & - \\
\hline $\mathrm{Fe}(\mathrm{III})$ & $18.54(1: 1)$ & - & - \\
\hline $\operatorname{Li}(\mathrm{I})$ & $7.18(1: 1)$ & $6.70(1: 2)$ & $5.90(1: 3)$ \\
\hline Mg(II) & $9.57(1: 1)$ & $7.20(1: 2)$ & $5.92(1: 3)$ \\
\hline $\mathrm{Ni}(\mathrm{II})$ & $8.79(1: 1)$ & $7.77(1: 2)$ & $5.60(1: 3)$ \\
\hline $\operatorname{Cr}(\mathrm{III})$ & $14.21(1: 1)$ & $10.83(1: 2)$ & $7.89(1: 3)$ \\
\hline $\operatorname{Sr}(\mathrm{II})$ & $8.60(1: 1)$ & $6.47(1: 2)$ & - \\
\hline Th(IV) & $18.02(1: 1)$ & - & - \\
\hline $\mathrm{Zn}(\mathrm{II})$ & $10.08(1: 1)$ & $8.91(1: 2)$ & $5.95(1: 3)$ \\
\hline $\mathrm{Cu}(\mathrm{II})$ & $11.95(1: 1)$ & - & - \\
\hline
\end{tabular}

* These ratios are from potentiometric and conductometric methods.<smiles>[X][M]Nc1c(Br)cc(Br)cc1CN(C)C1CCC(O)CC1</smiles>

Figure 5. Structure of M-AMB complex.

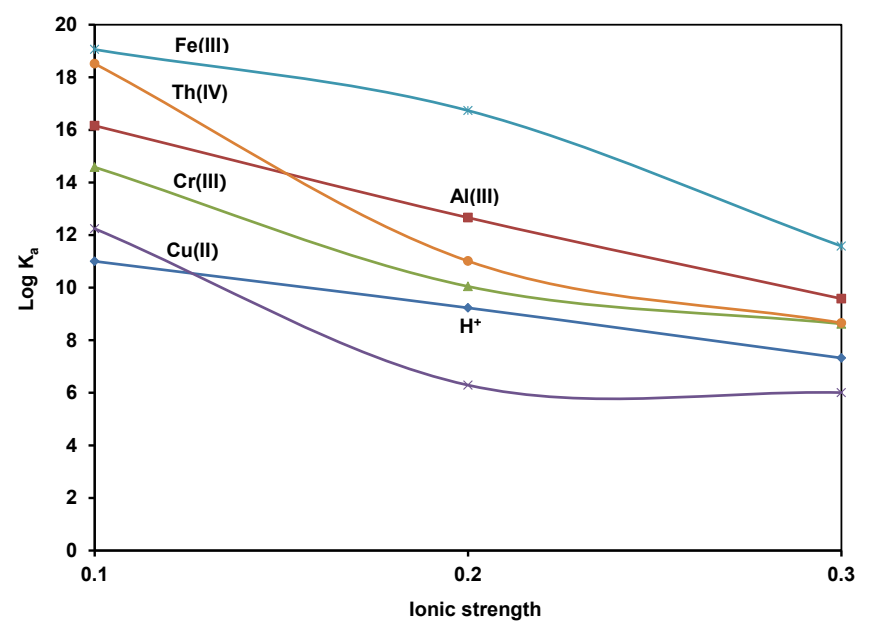

Figure 6. Effect of ionic strength on the stability constant of AMB with several metal ions.

The order of stability constants of the different binary complexes formed between $\mathrm{AMB}$ and bivalent metal ions investigated in this study shown an agreement with IrvingWilliams order [35] for (1:1) metal to ligand at $\mathrm{I}=0.1 \mathrm{M}$ $\mathrm{NaNO}_{3}: \mathrm{Pb}(\mathrm{II})>\mathrm{Cu}(\mathrm{II})>\mathrm{Cd}(\mathrm{II})>\mathrm{Zn}(\mathrm{II})>\mathrm{Mg}(\mathrm{II})>\mathrm{Mn}(\mathrm{II})>$ $\mathrm{Co}(\mathrm{II})>\mathrm{Ni}(\mathrm{II})>\mathrm{Sr}(\mathrm{II})>\mathrm{Ba}(\mathrm{II})>\mathrm{Ca}(\mathrm{II})$.

It was difficult to compare the results we had been obtained, due to the lack of data found in literature related to the formation constant of metal complexes formed between AMB and studied metal ions in current investigation. It is worth mentioning that the $\mathrm{pH}$-metric determination of the formation constant for binuclear complex species was not possible. This is due to the formation of such complexes occurred at high $\mathrm{pH}$ values, i.e. beyond the precipitation point for each system. On the other hand, the weak tendency of binuclear complex formation for this ligand can be attributed to the electron with drawing character of the six-membered chelate ring formed. This behavior can also be attributed to the steric effect which results from the electrostatic repulsions between the protonated metal complex and the metal ion. The observed high stability of Fe(III) complexes may be attributed to the unique electronic configuration of Fe(III) ion $\left(d^{5}\right)$, which is capable of additional stabilization due to Jahn-Teller distortion and the formation of six-membered rings which increases the stability of the formed complexes $[36,37]$.

The effect of ionic strength on stability constant of AMB with different metal ions viz. Fe(III), Th(IV), Al(III), Cr(III) and $\mathrm{Cu}(\mathrm{II})$ has been discussed. The studied ionic strength values were $0.1,0.2$ and $0.3 \mathrm{M} \mathrm{NaNO}_{3}$ at $25 \pm 0.1{ }^{\circ} \mathrm{C}$. By plotting the relation between the studied ionic strength values and the first stability constants $\log K_{1}^{H}$, we can conclude that the stability constants of metal-ligand complex (1:1) were decreased as the ionic strength increased (Figure 6). 

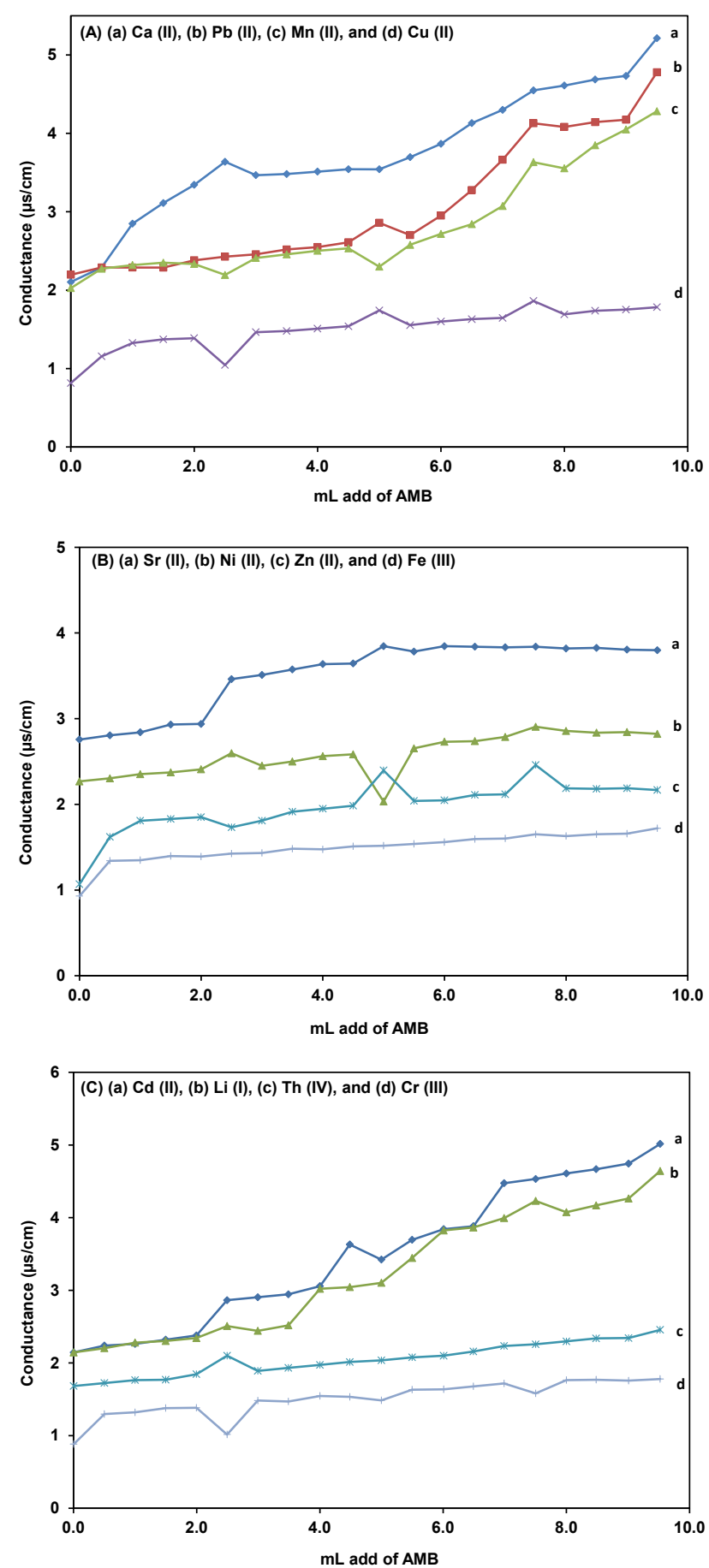

Figure 7. Conductometric titration curves of $25 \mathrm{~mL}$ of $1 \times 10^{-3} \mathrm{M}$ of studied metal ions with $1 \times 10^{-2} \mathrm{M} \mathrm{AMB}$

\subsection{Conductometric studies on the metal complexes of $A M B$}

Conductometric measurements can be applied for tracing complex formation in solution. This method has useful application as a sensitive tool to test for decimal variations in ionic radii of transition metal ions investigated. The conductometric analysis is based on changes in the electrical conductivity values of solutions as a result of complex formation. These changes depend upon the number of ions present, and their motilities. In this work, conductivity measurements are employed to trace the different types of chelate species formed between studied metal ions viz. Li(I),
$\mathrm{Mg}(\mathrm{II}), \mathrm{Sr}(\mathrm{II}), \mathrm{Ca}(\mathrm{II}), \mathrm{Mn}(\mathrm{II}), \mathrm{Co}(\mathrm{II}), \mathrm{Ni}(\mathrm{II}), \mathrm{Cu}(\mathrm{II}), \mathrm{Zn}(\mathrm{II}), \mathrm{Cd}(\mathrm{II})$, $\mathrm{Ba}(\mathrm{II}), \mathrm{Pb}(\mathrm{II}), \mathrm{Al}(\mathrm{III}), \mathrm{Cr}(\mathrm{III}), \mathrm{Fe}(\mathrm{III})$ and Th(IV) and AMB.

The conductometric titrations are performed by titrating of $25 \mathrm{~mL}\left(1 \times 10^{-3} \mathrm{M}\right)$ of each metal ion with successive volumes of $1 \times 10^{-2} \mathrm{M}$ AMB solution. Generally, on plotting the specific conductance values as a function of the added volume of AMB, these graphs are shown in Figure 7a-c. The obtained relationship shows a well-defined breaks corresponding to the stoichiometric ratios 1:1, 1:2 and 1:3 (M:L). These results show an excellent agreement with those obtained by potentiometric method (Table 1). 


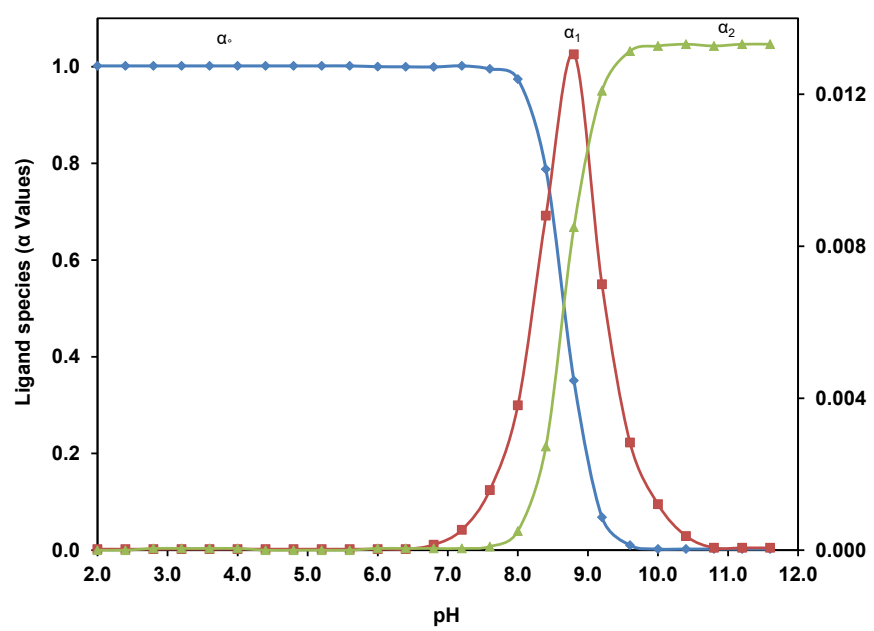

Figure 8. Ionic equilibria of AMB in different $\mathrm{pH}$ 's range.

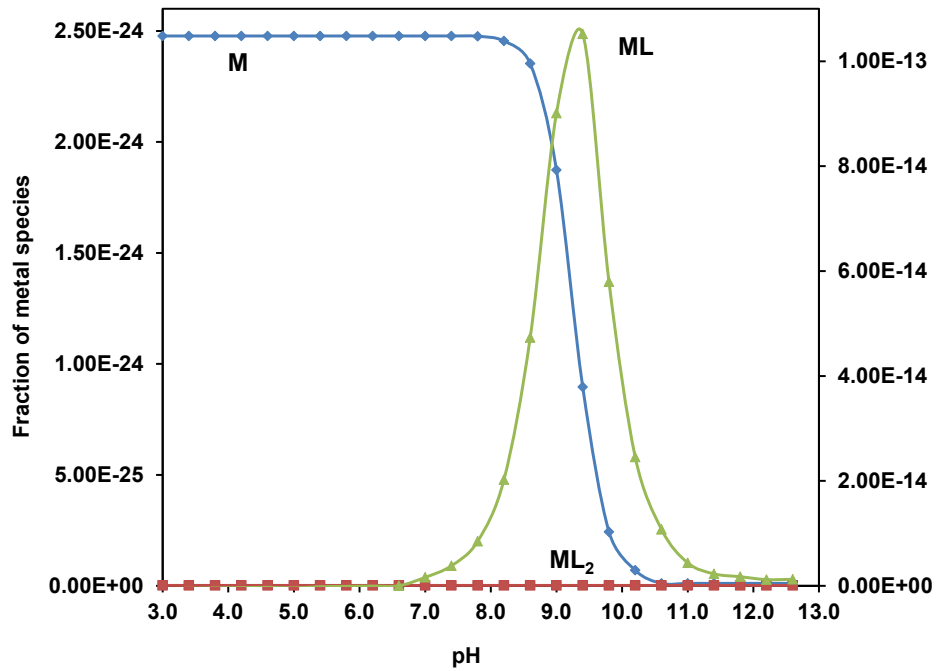

Figure 9. Ionic equilibria of $\mathrm{Al}(\mathrm{III})-\mathrm{AMB}$ complex in different $\mathrm{pH}$ 's range.

The observed increase in conductivity during the titration of metal ion with AMB during the complex formation, clearly indicate liberation of high ionic mobile $\mathrm{H}^{+}$ions. Thus chelation can take place through covalent bond between the metal ion and nitrogen atom of imino group $\left(\mathrm{NH}_{3}\right)^{+}$and liberation of hydrogen ions.

\subsection{Species distribution diagrams of AMB complexes}

Looking at the Figure 8, we can see that, in the $\mathrm{pH}$ range from 2.4 to 10.4, the major species of the ligand is $\alpha^{\circ}=\mathrm{H}_{2} \mathrm{~L}$ species, but in the $\mathrm{pH}$ from 6.8 to 11.6 , the $\alpha^{1}=\mathrm{HL}^{-}$species is the major one, as well as, the $\alpha^{2}=\mathrm{L}$ - species is the major in the $\mathrm{pH}$ range from 7.6 to 12.0 .

The mole fraction $\alpha_{\mathrm{ML}}$ and $\alpha_{\mathrm{ML} 2}$ can be calculated from potentiometric data using the obtained stability constant for $M L$ and $\mathrm{ML}_{2}$ complexes and the initial concentrations of metal ions and ligand [38]. The species distribution curves can be obtained by plotting $\alpha$ ( $\alpha=$ mole fraction of the species) $v s$. $\mathrm{pH}$. Curves for $\alpha$ as function of $\mathrm{pH}$ are depicted in Figure 8. Representative closely related plots were obtained for other metal-ligand complexes Figure 9.
On increasing the $\mathrm{pH}$ of medium, the concentration of metal ion tends to decrease, while that of ML species tends to developed at moderately acidic media $(\mathrm{pH} \approx 6.4-7.0)$. The values of $\alpha_{M}, \alpha_{M L}$ and $\alpha_{M L 2}$ present in solution depends mainly on the $\mathrm{pH}$ of the medium. In alkaline media, complex hydrolysis might be account for the decrease in concentration of the $\mathrm{Ba}(\mathrm{II}), \mathrm{Ca}(\mathrm{II})$ and $\mathrm{Sr}(\mathrm{II})$ complexes. The distribution curves show that complexation begins at $\mathrm{pH}$ values $\approx 6.00$, $6.30,6.40,6.45,6.50,6.55,6.60,6.62,6.70,6.72,6.75,6.80$, $6.83,6.85,6.89$, and 7.00 for $\mathrm{Ca}(\mathrm{II}), \mathrm{Li}(\mathrm{I}), \mathrm{Ba}(\mathrm{II}), \mathrm{Mg}(\mathrm{II}), \mathrm{Cr}(\mathrm{III})$, $\mathrm{Mn}(\mathrm{II}), \mathrm{Fe}(\mathrm{III}), \mathrm{Al}(\mathrm{III}), \mathrm{Cd}(\mathrm{II}), \mathrm{Ni}(\mathrm{II}), \mathrm{Cu}(\mathrm{II}), \mathrm{Zn}(\mathrm{II}), \mathrm{Co}(\mathrm{II})$, $\mathrm{Th}(\mathrm{IV}), \mathrm{Pb}(\mathrm{II})$ and $\mathrm{Sr}(\mathrm{II})$ complexes, respectively, as shown in Figure 9.

At $\mathrm{pH} \approx 7.1-11.8$, the essential change is the increase in the concentration of $\mathrm{ML}_{2}$ with decrease in ML. Above this region almost all of M(II) ion remains in the form of ML and $\mathrm{ML}_{2}$ species and their concentration increases on increasing the $\mathrm{pH}$ of solution. This demonstrates clearly that ML species are much more stable than $\mathrm{ML}_{2}$ in their solutions. This behavior is in line with stability constant values obtained for the chelates (Table 1). It is worth mentioning that with $\mathrm{Sr}(\mathrm{II})$, the ML species is dominant over the $\mathrm{pH}$ range of 7.0-11.6, with no 
significant $\alpha_{\mathrm{ML}}$ species of $\mathrm{Li}(\mathrm{I})$ and $\alpha_{\mathrm{ML} 2}$ species of $\mathrm{Al}(\mathrm{III})$, $\mathrm{Cd}(\mathrm{II}), \mathrm{Cr}(\mathrm{III}), \mathrm{Fe}(\mathrm{III}), \mathrm{Th}(\mathrm{IV})$ and $\mathrm{Zn}(\mathrm{II})$ even at high $\mathrm{pH}$ values.

\section{Conclusion}

Herein, a potentiometric and conductometric studies of binary complexes of ambroxol hydrochloride and several important metal ions; $\mathrm{Li}(\mathrm{I}), \mathrm{Mg}(\mathrm{II}), \mathrm{Sr}(\mathrm{II}), \mathrm{Ca}(\mathrm{II}), \mathrm{Mn}(\mathrm{II}), \mathrm{Co}(\mathrm{II})$, $\mathrm{Ni}(\mathrm{II}), \mathrm{Cu}(\mathrm{II}), \mathrm{Zn}(\mathrm{II}), \mathrm{Cd}(\mathrm{II}), \mathrm{Ba}(\mathrm{II}), \mathrm{Pb}(\mathrm{II}), \mathrm{Al}(\mathrm{III}), \mathrm{Cr}(\mathrm{III}), \mathrm{Fe}(\mathrm{III})$ and Th(IV) were achieved in aqueous medium. The determination of proton ligand association constants of ambroxol hydrochloride and their metal complexes, in $0.01 \mathrm{M} \mathrm{HNO}_{3}$ and $\mathrm{I}=0.1 \mathrm{M} \mathrm{NaNO}_{3}$ was investigated and the two logarithmic association constant values which calculated by the half- $\bar{n}$ method were 10.7 and 7.6, respectively. Both of potentiometric and conductometric methods proof that the formed metal complexes have a stiochiometric ratios of 1:1, 1:2 and 1:3 (M:L). Finally, the species distribution of ambroxol hydrochloride and its metal complexes under investigated are variables during the $\mathrm{pH}$ 's ranges.

\section{Disclosure statement $0 s$}

Conflict of interests: The authors declare that they have no conflict of interest.

Author contributions: All authors contributed equally to this work.

Ethical approval: All ethical guidelines have been adhered.

Sample availability: Samples of the compounds are available from the author.

\section{ORCID}

Ahmed Hosny Naggar

(iD) https://orcid.org/0000-0001-5492-6114

Hammed Mohammed Al-Saidi

(iD https://orcid.org/0000-0002-5421-435X

Othman Abd El-Moaty Farghaly

(iD) https://orcid.org/0000-0001-7717-9553

Taher Mohammed Hassan

(iD https://orcid.org/0000-0003-1196-7914

Salma Zaidan Mohamed Bortata

(iD) https://orcid.org/0000-0001-6459-2066

\section{References}

[1]. The Merck Index, An Encyclopedia of Chemicals, Drugs and Biologicals, 13 ${ }^{\text {th }}$ Ed. , Merck and Co. Inc. , Whitehouse Station, NJ, 2002.

[2]. Heinanen, M.; Barbas, C. J. Pharm. Biomed. Anal. 2001, 24, 1005-1010.

[3]. Olivieri, D.; Zavattini, G.; Tomasini, G.; Damiotti, S. Respiration 1987, $51,42-51$.
[4]. Fraschini, F.; Scaglione, F.; Scarpazza, G.; Marchi, F.; Calzavara, M. Curr. Ther. Res. 1988, 43, 734-742.

[5]. VanPetten, G. R.; Mears, G. J.; Taylor, P. J. Am. J. Obs. Gynecol. 1978, 130, 35-40.

[6]. Salzer, H.; Weidinger, H.; Simbruner, G.; Vytiska-Binstorfer, E. Z Geburtshilfe. Perinatol. 1986, 190, 49-59.

[7]. British Pharmacopeia, Vol II, British Pharmacopeia Commission, 1529, 2014.

[8]. India Pharmacopeia, Vol II, India Pharmacopeia Commission, Ghaziabad, 1025, 2014.

[9]. Hambley, T. W. Dalton Trans, 2007, 4929-4937.

[10]. Orvig, C.; Abrams, M. J. Chem. Rev. 1999, 99, 2201-2203.

[11]. Guo, Z.; Sadler, P. J. Angew. Chem. Int. Ed. 1999, 38, 1512-1531.

[12]. Sadler, P. J.; Zijian, G. Pure Appl. Chem. 1998, 4, 863-871.

[13]. Bruijnincx, P. C. A.; Sadler, P. J. Curr. Opin. Chem. Biol. 2008, 12, 197206.

[14]. Rossotti, F. J. C.; Rossotti, H. The Determination of Stability Constants and Other Equilibrium Constants in Solution, McGraw-Hill Book Company, Inc. , New York, 1961.

[15]. Amrallah, A. H.; Abdalla, N. A.; El-Haty, E. Y. Talanta 1998, 46, 491500.

[16]. Abdel-Gaber, A. A.; Farghaly, O. A.; Ghandour, M. A.; El-Said, H. S. Monatsh. Chem. 2000, 131, 1031-1038.

[17]. Abdel-Latif, N. M.; Abdel-Wadood, H. M.; Farghaly, O. A. Egypt J. Anal. Chem. 2006, 15, 71

[18]. Ghandour, M. A.; Aboul-Kasim, E.; Amrallah, A. H.; Abdalla, N. A.; Farghaly, O. A. J. Indian Chem. Soc. 1999, 76, 480-482.

[19]. Ghandour, M. A.; Aboul-Kasim, E.; Amrallah, A. H.; Farghaly, O. A. J. Indian Chem. Soc. 1993, 70, 615-617.

[20]. Farghaly, O. A.; Mohamed, N. A.; Gahlan, A. A.; El-Mottaleb, M. A. Indian J. Anal. Chem. 2008, 7, 294-300.

[21]. Naggar, A. H.; Mauof, H. A.; Ekshiba, A. A.; Farghaly, O. A. Pharm. Chem. J. 2016, 3, 125-137.

[22]. Yousef, W. M.; Alenezi, K.; Naggar, A. H.; Hassan, T. M.; Bortata, S. Z.; Farghaly, O. A. Int. J. Electrochem. Sci. 2017, 12, 1146-1156.

[23]. Farghaly, O. A.; Al-Saidi, H. M.; Naggar, A. H.; El-Mabrouk, I. M. Int. J. Electrochem. Sci. 2017, 12, 9865-9881.

[24]. Al-Rashdi, A. A.; Naggar, A. H.; Farghaly, O. A.; Mauof, H. A.; Ekshiba, A. A. Am. J. Anal. Chem. 2018, 9, 99-112.

[25]. Farghaly, O. A.; Mohamed, N. A.; Hazzazi, O. A. , Gahlan, A. A.; Mottaleb, M. A. Res. Rev. Electrochem. , An Indian J. 2010, 2, 6-14.

[26]. Ghandour, M. A.; Azab, H. A.; Hassan A.; Ali, A. M. Monatsh. Chem. 1992, 123, 51-58.

[27]. Quang, D. T.; Kim, J. S.; Chem. Rev. 2010, 110, 6280-6301.

[28]. Daniele, G. P.; Zerbinati, O.; Zelano, V.; Ostacoli, G. J. Chem. Soc. Dalton Trans. 1991, 2711-2715.

[29]. Levinson, W.; Oppermann, H.; Jackson, J. Biochim. Biophys. Acta 1980, $606,170-180$

[30]. Chain-Stier, C. H.; Minkel, D.; Petering, D. H. Bioinorg. Chem. 1976, 6, 203-217.

[31]. Kirschner, S.; Wei, K. Y.; Francis, D.; Bergam, G. J. J. Med. Chem. 1966, 9, 369-372.

[32]. Meloun, M.; Syrovy, T.; Vrana, A. Talanta 2004, 62, 511-522.

[33]. Mohamed, H. A.; Wadood, H. M. A.; Farghaly, O. A. J. Pharm. Biomed. Anal. 2002, 28, 819-826.

[34]. Irving, H.; Rossoti, H. S. J. Chem. Soc. 1953, 3397-3405.

[35]. Irving, H.; Williams, R. J. P. Nature 1948, 162, 746-747.

[36]. Wang, B.; Chung, C. S. J. Chem. Soc. Dalton Trans. 1982, 2565-2566.

[37]. Paoleltti, P.; Fabbrizzi, L.; Barbucci, R. Inorg. Chem. 1971, 12, 18611964.

[38]. Beck, M. T.; Chemistry of Complex Equilibria, Van Nostrand Reinhold, London, 1970.

\section{() $(1) \Theta$}

Copyright (c) 2018 by Authors. This work is published and licensed by Atlanta Publishing House LLC, Atlanta, license are available at http://www.eurjchem.com/index.php/eurjchem/pages/view/terms and incorporate the Creative Commons Attribution-Non Commercial (CC BY NC) (International, v4.0) License (http://creativecommons org/licenses/by-nc/4.0). By accessing the work, you hereby accept the Terms. This is an open access article distributed under the terms and conditions of the CC BY NC License, which permits unrestricted non-commercial use, distribution, and reproduction in any medium, provided the original work is properly cited without any further permission from Atlanta Publishing House LLC (European Journal of Chemistry). No use, distribution or reproduction is permitted which does not comply with these terms. Permissions for commercial use of this work beyond the scope of the License (http://www.eurjchem.com/index.php/eurjchem/pages/view/terms) are administered by Atlanta Publishing House LLC (European Journal of Chemistry). 